\title{
Forensic Accounting and Fraud Control in Nigeria: A Critical Review
}

\author{
Ugwu, James Ike Ph.D \\ Department of Accounting and Finance, Godfrey Okoye University, Enugu, Nigeria \\ e-mail: jugwu@gouni.edu.ng
}

\begin{abstract}
Fraud control in Nigeria has been a very difficult issue in Nigerian public sector and seems to have been institutionalized in the country owing to many years and increasing cases of fraudulent activities by public office holders. The recent wave of the use of forensic accounting/auditing in Nigeria have attracted wide acceptance as possible panacea to the menace of fraud in Nigerian public sector. To this end, the study critically reviewed the application of forensic accounting in fraud detection, investigation and litigation support services. The study adopted descriptive research design with extensive and intensive literature review. It was concluded that the emergence/ introduction of forensic accounting contributes significantly in fraud control however, it seems not to be a complete panacea for fraud issues in Nigeria. The study recommends amongst others that fraud detection should be enshrined as part of auditors work by the policy makers so that non detection of fraud would attract sanctions to the auditor concerned. Also, training and retraining of forensic accountants on court process to avoid loss of good cases to avoidable court technicalities.
\end{abstract}

Keywords: Forensic Accounting, Fraud detection, fraud investigation, litigation support, Public Sector

DOI: $10.7176 /$ RJFA/12-10-13

Publication date:May $31^{\text {st }} 2021$

\section{Introduction}

Historically accounting is as old as man when God after creation, took account of what He created and saw that it was good. He subsequently place man in charge of the created and man was expected to give account of his stewardship. Furthermore, as economic activities of man increased oral reports were usually subjected to interrogation to ascertain the correctness of the report to the owners of the business. As business becomes complex and record keeping developed, auditing evolved along-side with it.

Some forensic accounting experts traced fraud history to the ancient Egypt in respect of those who took inventory of Pharoah's valuables like grains and gold. Embezzlements and bribes then were very minimal and punishment for culprits very harsh. Archaeological findings in Mesopotamia and Egypt in 3300 B.C and 3500 B.C respectively showed evidence suggestive that accountants/scribes recorded economic transactions using clay tables of papyrus scrolls. Any suspicion of tampering with the record would result in the original one being enfolded and wrong doings fined and serious cases of mutilation might attract death (Oyedokun, 2012 and Zysman, 2004).

Furthermore, Oyedokun (2019) added that evidence of forensic accounting were also found in India between 321 B.C. and 184 B.C. in which 40 crimes were considered embezzlement with punishment for those found culpable. Also, they added that accounting historians were able to have reference to at least three cases between $16^{\text {th }}$ and $18^{\text {th }}$ centuries where individuals responsible for accounting records provided evidence as expert witness in Europe and Britain.

These days, forensic accounting has developed in that we have Association of Forensic Accounting Researchers (AFAR) who certify members in various areas in forensic accounting like Certified Forensic Accountants (CFAt), Certified Forensic Auditor (CFAr), Certified Forensic Investigators (CFI) and so on.

Fraud is so pervasive in Nigeria in that it is becoming a way of life. Hope and Chikuloas in Osisioma (2012) averred that corruption is rare in Botswana, widespread in Ghana and systemic in Nigeria. For fraud to be systemic in Nigeria, it implies that fraud in Nigeria is an industry; which means it has stakeholders, investors and risk-return profile. The fraud industry is organised, with internal coordination, shared knowledge and share of benefits linking principals and agents and shares reward among the stakeholders. The system on its own grows practitioners at every level, from school to graduation, from childhood to adulthood, from micro to macro levels; thus there is sustained supply of individuals which ensure that fraud is maintained in perpetuity. People actually expecting leaders to be corrupt, with anything short of that as being too good to be true, as such persons are considered fools. The system actively discourages people with integrity and character, with high price tag for public office, for men 
of character-sacrifice of personal integrity. In the system, leaders were not held accountable, with ethnic and sectoral loyalty overriding character and competence.

In the light of the above, fraudulent activities has become institutionalized in that it has become a way of life and one is expected to be 'corrupt' in line with what is now the 'norm'. For instance refusal to receive gratification in public service would be viewed as abnormal and frowned at by friends and associates and where your position would prevent possible beneficiaries from getting their own share, it would be resisted by all means including threat to life. An attempt to report such threat from colleague to kinsmen and some higher authorities may be met with mockery comments and removal from office in some instances as you are awkward, a mismatch and antiprogress.

Public sector organisations are not privately owned as such are established for public good. They provide services at nil cost or subsidized prices. They operate public utilities, regulatory organisations and sometimes as a commercial enterprise. Performance evaluation in public sector is hindered by lack of profit motive and presence of intangible services whose benefits are difficult to quantify (Adams, 2006). Being publicly owned implies that those in authority are managing the organisation on behalf of the citizens and handle their assets in thrust. The above, breed in some quarters, that it is nobody's business, as such a fertile ground for fraud and corrupt practices. Various measures have been put in place to control and regulate the activities of these organisations through laid down policies and procedures as well as some Acts (laws). It is in the response to the public demand to curb corruption and fraudulent practices that gave birth to forensic accounting, hence the study to critically ascertain the contribution of forensic accounting to fraud control in Nigerian public sector.

\section{Statement of the Problem}

In the modern time, accounting profession has been battling with what they considered as their professional requirements (roles) in terms of accounting and auditing and what the public generally feel and expected from them. This is commonly refered to as audit 'Expectation Gap'. It is in the face of the challenges of expectation gap that brought to the front burner issues bordering on forensic accounting cum auditing. These two emerging seamis twin in the accounting profession focus on solving some challenges in the system; in area of fraud detection, investigation, remediation and litigation support services. Forensic accounting and auditing were tailored towards presentation of evidence admissible in court. Forensic accounting relates to application of financial facts to legal problems. It includes any financial investigation that can result in legal consequences. Expectedly, forensic accounting should be able to tame the tide of fraudulent practices through fraud detection, fraud investigation, litigation support services and fraud remediation.

However, the situation in Nigeria is so pathetic such that the rate and volume of fraudulent activities were very high such that in 2019 Corruption Perceptions Index (CPI), Nigeria scored 26 percent, clinching $146^{\text {th }}$ position out of 180 countries sampled. In Nigeria, there have been some high level corruption cases like the over 8.5bn naira alleged no remittance of recovered fund by Economic and Financial Crime Commission (EFCC) leadership, the alleged diverted 1.9bn naira Ebola fight fund, the \$20bn NNPC case, the famous 'Arm Scam Deal' of \$2 bn of 2015 and N5.5bn Niger Delta Development Commission (NDDC), 2020, contract scam involving Signora Concept Services LTD amongst others.

Most of the suspected cases have not been fully investigated or prosecuted to a logical conclusion such that there have been questions as to what might have been the causes, among which is suspected lack of adequate evidences for diligent prosecution. The financial evidences were expected to come from financial experts like the forensic accountants. It is in the light of the above that the study critically evaluated the contributions of forensic accounting towards fraud control in Nigeria especially in the public sector.

\subsection{Objectives of the Study}

The study evaluated the contribution of forensic accounting in fraud control in Nigeria. In specific term it sought to

1. Ascertain the contributions of forensic accounting in fraud detection in Nigerian Public Sector.

2. Evaluate the contributions of forensic accounting in fraud investigation in Nigerian Public Sector.

3. Establish the contributions of forensic accounting in the provision of litigation support services in Nigerian Public Sector.

\subsection{Research Questions}

The research battled for answer to such questions as

1 What are the contributions of forensic accounting towards fraud detection in Nigerian Public Sector. 
2 How does forensic accounting help in fraud investigation in public sector in Nigerian.

3 To what extent does forensic accounting provide ligation support services in Nigerian Public Sector.

\subsection{Review of Related Previous Works}

The concept of forensic accounting and fraud were reviewed, as well as, literatures on forensic accounting and fraud detection and investigation, in addition to, literatures on forensic accounting and litigation support services. Theoretical base of the work was equally explored plus empirical review.

\subsection{Concept of Forensic Accounting}

Forensic accounting has been defined by Association of Certified Fraud Examiners (ACFE) (2019) as the use of accounting skills in matters involving potential or actual civil or criminal litigation, covering amongst other areas, generally accepted accounting and auditing principles; lost profit determination, income, asset or damages; internal control evaluation; fraud and any other matter requiring accounting expertise in legal system. Furthermore, Howard and Sheetz (2006) in Oyedokun (2019) see forensic accounting as a process of interpreting, summarizing and presenting complex financial issues clearly, succinctly and factually often in a court of law as an expert. Similar definition was given by Hopwood, Leiner and Young (2008), in which they argued that forensic accounting is the application and analytical skills for resolving financial issues in a manner that meets court standard. Webster's Dictionary (2000) sates that forensic accounting provides an accounting analysis that is suitable to the court which will form the basis for discussion, debate and ultimately dispute resolution. It added that forensic accounting encompasses litigation support and investigative accounting.

The study, therefore, defines forensic accounting as the process of applying auditing and investigative techniques in obtaining evidences relating to financial matters in a manner suitable for adjudication in the court. The process provides the basis for conviction or otherwise of suspected fraud cases.

These imply that Forensic Accountant utilizes accounting, auditing and investigative skills when conducting an investigation. They communicate financial information clearly and concisely in a courtroom setting. By their training, they look beyond the numbers while ordinary accountants look at the numbers. In view of the afro said, there is no clear division between the term forensic accounting and forensic auditing. In carrying out the work, forensic accounting is sufficiently thorough and complete so that an accountant in his independent judgment can deliver a finding as to accounts, inventories or the presentation thereof that is of such quality that it would be sustainable in some adversarial legal proceeding, or within some judicial or administrative review (Okoye, Maimako, Jugu \& Jat, 2017).

In view of demands from accountants and the environment of operation, Okoye et al (2017) argued that since all professional accountants operate within a commercial legal environment, all professional accountants are in a sense, forensic accountants stressing that what distinguishes a forensic accounting in common parlance are the engagement. They went further to contend that when the accountant expects that their findings or analysis may be subjected to adversarial or judicial scrutiny or administrative review, he seeks a level of evidentiary details and analytical precision which would be sustainable within the legal framework of such scrutiny or review. The implication of the above assertion is that the nature of work and possibility of subjection to further analysis determines the details required. Therefore, the ability of the professional accountant both in training and experience, guides him in his acceptance or otherwise of his engagement(s).

\subsection{Concept of Fraud}

Fraud according to Meigs, Larsan and Meigs (1977) is the misrepresentation by a person of a material fact, known by that person to be untrue or made with reckless indifference as to whether the fact is true, with the intention of deceiving the other party and with the result that the other party is injured. Similarly, Udeh and Ugwu (2018), define fraud as intentional misstatement of facts (falsification or fabrication) with the intention to benefit or conceal shoddy deals such that reliance on the information may be misleading resulting eventually in loss to users.

\subsection{Forensic Accounting and Fraud Detection and Investigation}

Whenever there is irregularity, errors or misstatement, it arouses curiosity as to the correctness or otherwise of the financial report. In such situation, the auditor conducts an investigation to ascertain whether there is fraud or error. The word 'investigation' is derived from Latin word vestigere which means to 'track or trace'. It involves systematic inquiry comprising processes or procedures resulting in successful planning and execution of appropriate line of inquiry to obtain evidence required to obtain factual basis of the matter concerned.

For successful conduct of the investigation in financial crime, one should realize that they are filled with complexity and they are by nature information intensive. Okafor (2006) states that you have to approach 
investigation of financial crime by: getting organised and the process of proof. In getting organised, you have to bear in mind that it is an extension of legal process. As a result the investigator should think like a lawyer from the ground up so as to build a strong case, as we know, a lawyer has to prove a case beyond reasonable doubt. These acts are defined with relative clarity, by codified laws and legal precedence. Thus, there should be massive audit evidence and the audit has to be carried out within the confines of relevant law and withstand legal scrutiny. The process of proof involves getting relevant evidence and inferences. An evidence is relevant if it tends either to prove or disprove the issue in contention. Inference relies on chain of logic that must be forged one link at a time. The inference on which guilt is based must be linked together in a logical, linear way and conform to a narrow frame work of rigorously enforced rules. In effect, to fully understand how to build a chain of logic, the investigator must grasp with the logic underpinning legal arguments. The most common two were the deductive argument (this works from general to specific) and inductive argument (from series of observation to reach at conclusion).

Furthermore, the investigator must think like both a thief and a detective, as such, must be constantly looking for the weak links in accounting system and among the people who staff it. In the conduct of the investigation, he must be prepared to reach far beyond the company's books, to industry and government information, proprietary data bases, court records and any other source that might throw light on the case.

It is worthy of note that the accounting professional plays two important roles in any forensic investigation: as lead financial investigator and potential expert witness in any subsequent civil or criminal trial. As lead investigator, he understands the internal control and know how to trace the flow of funds into, through and out of the organisation. They are in position to provide an independent, objective critique of the corporate organisation not only in the problems in the accounting system that permit the fraud to occur but also address the integrity of the people at the heart of the process. As expert witness, the professional knows the rules of evidence, what documents to request, whom they should interview and in civil case, how to do damage quantification arising out of the situation.

Businesses and public sector organisations could be victim of both internal and external fraud and also a combination of the two. Internal frauds are usually perpetrated by the employees while external frauds are deception committed by outsider against the organisation. In some cases, an employee may collude with an outsider to defraud the organisation. There is also management fraud committed by senior personnel who can override controls to prevent fraud. It is serious as management fraud set up negative model for employees below the orgainsation ladder. Conversely, we have corporate fraud in which the senior management commits fraud that benefit the organisation examples are tax evasion, production of unsafe products, financial statement fraud, false advertisement and environmental crimes. Fraud could take one of two forms: defalcations and manipulations (Aguolu, 2018). Defalcation involves stealing cash, stock or other assets while manipulation without defalcation involves inflating assets or omitting liabilities. Usually, defalcation goes with manipulation.

In audit for fraud, the pattern to look for are the exceptions and oddities, that is, things that do not fit in organised scheme because they are too large, too small, too frequent, too rare, too high, too low, too ordinary, too extra ordinary, too many or too few or feature odd times, odd places, odd hour, odd people and odd combination. Thus, one looks for the unusual rather than the usual (Okoye, 2006). Therefore, for complete assessment of fraud data that precedes or follows a questionable transaction should be available. This implies that one goes behind and beyond those transactions to reconstruct what may have led to them and what has followed from them.

Fraud detection Methods

Primary ways to detect fraud includes

- By Accident

- By installing hot lines and whistle bowing system that encourage employees and other people to report suspected cases of fraud

- Examining transaction records, accounts and documents and other abnormality that might indicate fraud.

Fraud Investigation Steps

Five steps approach to forensic accounting according to Singleton, Singleton, Bologna and Lindquist (2006). The steps include: 
a. Predication: that is a set of circumstances that convince reasonable, prudent and professional trained individual that fraud has occurred, is occurring or is about to occur.

b. Fraud investigation plan: based on forensic auditors knowledge and analysis of fraud scheme and the red flags associated with them.

c. Examination of records and evidence gathering: to confirm or otherwise of the fraud, accounting, and transaction documents, as well as, other data are examined.

d. Interview process: eye witness and later, the suspect are interviewed.

e. Report writing: the report is written and submitted to the person who engaged the forensic auditor. The report should be clearly and carefully worded bearing in mind that should the case be brought to court, it would be relied upon for judgement.

Nigeria has been engaging forensic auditors in its public sector. For instances, forensic auditors were appointed and audited the Nigeria National Petroleum Corporation (NNPC) by Price Water Coopers (PWC) with report of over 46 percent of revenue spent on operational cost and subsidies. The report is also suggestive that NNPC would be unable to sustain monthly remittances to the Federation Account Allocation Committee (FAAC), and also meet its operational costs entirely from the proceeds of domestic crude oil revenues, and have had to incur third party liabilities to bridge the funding gap, amongst others. Furthermore, in Vanguard (2020, August 26) it was reported that federal government appointed forensic auditors for comprehensive audit of Niger Delta Development Commission (NDDC) following EFCC report of suspected fraud in the organisation.

Some empirical works were reviewed to ascertain the findings of some scholars who have carried out research in this area of interest. For instances:

Adekoya, Oyebamiji and Lawal (2020) explored the use of forensic accounting in the control of tax fraud and tax evasion. Using exploratory research design, the study concluded that traditional auditing has failed in curbing tax fraud and tax evasion and that forensic accounting would expose, control and deter fraudulent practice on tax revenue. In a similar study, Adesina, Erin, Ajetunmobi, Ilogho and Asiriuwa (2020) sought to ascertain whether forensic audit influence fraud control in Nigeria with evidence from Nigeria Deposit Money Banks (DMBs). Survey research design was adopted for the study. Ordinary Least Square analysis of data collected revealed that involvement of qualified and experienced forensic auditors would not only help in ameliorating frauds in DMBs but would also lead to sanity in the banking sector.

In their study, Agu and Okoye (2019) evaluated the application of forensic accounting as a means of bridging audit expectation gap in Nigerian deposit money banks in Enugu state. Data collected from the survey study were analysed using Pearson Product Moment Correlation. Finding suggested a significant relationship between forensic investigation and expectation gap.

Coversly the study of Bassey and Ahonkhai (2017), on the effect of forensic accounting on litigation support on fraud detection in banks in Nigeria, using questionnaire for data collection and ANOVA for data analysis revealed that they do not have significant effect on fraud detection. However, Fiergbor, (2020) evaluated managing projects using forensic accounting in detection and prevention of fraud in Ghana. Qualitative analysis revealed that irrespective of the nature of the fraud, forensic accounting could control it.

Relevance of forensic accounting: issues in accounting and auditing practice in Nigeria was examined by Ejike (2018), in which he adopted interview and questionnaire survey methods. Result of data analyses using simple percentage and t-test were suggestive that forensic services were required in curbing fraudulent practices in Nigeria.

Gbegi and Adebisi(2014) investigated the application of forensic accounting skills and techniques in fraud investigation in the Nigerian public sector. Primary data were collected by the use of questionnaire and secondary data from EFCC, ICPC and CCB were analysed using ANOVA. One of the findings is that forensic accounting skills and techniques have significant effect on uncovering and reducing fraud in Nigerian public sector. Similarly, Okoye, Adeniyi and James (2019), reviewed effect of forensic accounting and fraud management on selected firms in Nigeria. Data collected using questionnaire were analysed using descriptive statistics and hypotheses tested by means of regression. It revealed that forensic accounting significantly influence fraud detection and prevention.

In another study, Onubiko Nwankwo and Achara (2019), examined the extent forencsic accounting has effect on fraud management of organisations in Nigeria. Primary and secondary data for the study were analysed using Semantic Differential Scale to establish the significance of the hypothesis. Result showed significant correlation 
between fraud detection, reduction, and prevention engendered by forensic accounting and good management practices.

\subsection{Forensic accounting and Litigation Support Services}

This could be approached through providing evidence and testifying as expert witness in the court for effective prosecution and judgement, as well as, determination of appropriate compensation (remediation) to victims of fraudulent acts. It involves interpretation, organising and presentation of facts systematically and scrupulously for effective adjudication in the court.

\subsection{Theoretical Review}

\section{The Anomie Theory}

The theory is associated with Merton and Chinoy (1957). The theory tends to explain the pressure the society exert on members that lead to anti-social behaviours including fraud/corruption. They argue that the society set goals for individuals and groups and also prescribes the means of attaining them. Some individual resources were not enough to attain the expectation of the society, this brings about corrupt and unethical behaviours. The society also send messages of what is normal and acceptable behaviour to individuals through societal institutions. 'Normal' is that which is psychologically acceptable and sometimes, culturally approved. However, pressure from the society might compel most individuals to engage in unethical behaviours like fraud/corruption. Merton therefore, asserts that criminal behaviours are functions of emphasis on goal of accumulation of wealth with a great disconnect with the goal value of the society and the means available to achieving the goal (Murphy \& Robinson, 2008).

The above is appropriate for the study as Nigerian society emphasizes goal attainment without any recourse to the legitimate means of attaining the goal. Individuals who are economically buoyant are hailed and held in high esteem in the society not-withstanding the means of his accomplishing it. This value system breeds various forms of corrupt practices like bribery, embezzlement, examination malpractices, fraud etc.

\section{Methodology}

The study adopted descriptive research design. Information regarding the study were gathered from published and unpublished sources hence it was extensive and intensive. Careful review of relevant journals, articles, books, workshop documents etc were done to explore the topic. From the works read, conclusion was made.

\section{Discussion}

The visit of forensic auditors to an organisation does not only help in fraud investigation and litigation support but also in fraud prevention through its spin-off effect. Attentions of forensic auditors are usually attracted to the unusual, which arouse their curiosity to conduct detailed investigation on the matter(s) concerned. In the investigation, everything is important as not-withstanding how minor or immaterial it may appear, it may be a clue to existence of big fraud. This implies that in forensic accounting/auditing, all evidences are considered material and fully investigated. The difference between auditors and forensic auditors is on the degree of thorough and painstaking approach to audit process. Today, as it was in the case of auditors before, the mention of the coming of forensic auditors to an organisation is received with panic and fright with scrupulous cleansing of records.

The effectiveness of the forensic accountants in filling the audit expectation gap seems not to be in doubt to most scholars but the system we operate tends to stifles' the output viz:

a. Low risk-high benefit theory i.e plea-bargaining: EFCC Act Section 14(2) provides option of plea bargain. Usually, the accused is required to enter into arrangement to refund some money or assets which are highly immaterial compare to the alleged fraud. The charge is then drop on payment/ surrender of such asset. For instance former Edo State governor who was charge by EFCC for money laundering and embezzlement amounting to N2.9b had his 191 count charge dropped to 1 and when he pleaded guilty he was asked to pay N500m and return three properties which he quickly complied and was set free.

b. The existence and abuse of presidential pardon: Section 175(1) of 1999 constitution (as amended) confers on the president pardoning power in federal offences. A political allies if eventually convicted of fraudulent acts and sentenced to imprisonment are usually left of the hook by the president on the cover that he is exercising that prerogative of mercy. Such was the case when D.S.P. Alamieyeseigha former governor of Bayelsa State was impeached by the state house of assembly in $9^{\text {th }}$ December, 2005 and arraigned by EFCC in Federal High court Lagos and found guilty of on six 
count charges of corruption and money laundering in July 2007 and was granted pardon by President Goodluck Jonathan, in March 12, 2013.

c. The immunity clause: Section 308 (1) of 1999 constitution shields the President, Vice President, Governors and Deputy Governors from criminal and civil prosecution for any offence committed while in office. It protects them against arrest, application or issuance of court process requiring their appearance, commencement or continuance of civil of criminal proceedings and detention/imprisonment. This provision had promoted acts of impunity including corrupt and fraudulent activities.

d. The societal value system- the anomie theory

e. Religious hypocrisies: the manner religious leaders turn their eyes away from how wealth are made but respect and even arrange special thanks giving services for corrupt rich persons promotes corruption and fraudulent activities in the society.

f. Lack of sustainable development resulting in extreme poverty, rising unemployment etc. In Nigeria there seems no plan for the future generations as we are busy tapping the oil which would be exhausted sometimes in future without strong policy and actions to provide for the upcoming generation. Those in position of thrust tends to save for their generation fraudulently while poverty has been on the increase. In 2019, 83 million people representing 40 percent of Nigerian population were below poverty line, that is, below 137430 naira (\$381.75) per year (World Bank, 2020). In 2018, the population was 82.9 representing 40 percent

g. Allegiance to political party and political associates which breeds corruption: in Nigeria, there seems to exist a big shield for political office holders for whatever they do, as far as, they pay and maintain allegiance to the ruling party. The ruling class rally round their colleagues accused of fraud/corruption to cover up the shoddy deals. This has contributed significantly to weak institutions as the politicians in power interfere with the duties of the anti graft agencies through undo pressure from their contacts (friends and cronies).

In 2015, the then president of Nigeria, Goodluck Jonathan was quoted as saying that stealing is not corruption in an attempt to distinguish the Straight Act of Stealing from other forms of corruption. In effect, Nigerians have strong hatred for thieves than corrupt people as in an attempt to describe a corrupt officer as a thief to drive home the degree of what he did will be received with such comment as agreed he is a thief but should be described as 'opportunist', a 'sharp man', 'our man'. Thus, diverting public fund to better your family, friends and constituency could be baptised and less frowned at hence fraud in public sector has continued to grow and flourish as industry.

h. Weak institutions which comprises among others the police; anti graft agencies like the Code of Conduct Bureau, Economic and Financial Crime Commission (EFCC), Independent Corrupt Practices and other Related Offences commission (ICPC); Due Process; Bureau of Public Enterprise and Bureau of Public Procurement; the court etc. Undo political interference have rendered most of them 'lame dogs' who only bark but do not bite. This could be seen from the fact that hardly would any fraud/corruption cases be fully investigate and prosecuted with desired result.

The implication of the above is that fraud would continue to occur in Nigeria despite the good work of forensic accountants/auditors because of the above factors. A combination of the above factors have resulted in people engaging in corrupt and fraudulent activities, according to the ability of their position in the public sector organisation. This is due to the belief that there will be a way out.

\section{Conclusion and Recommendations}

The emergence/ introduction of forensic accounting contributes significantly in fraud control however, it seems not to be a complete panacea for fraud issues in Nigeria. They rekindled the hope of the public on auditors who have had serious reputational damage over the years as they were perceived to have had hands in glove with the management, thus, most of them being perceived to have compromised standard and ethical requirements in the conduct of their work.

The study recommends as follows

1. Fraud detection should be enshrined as part of auditors work by the policy makers so that non detection of fraud would attract sanctions to the auditor concerned. This would reduce the expectation gap and 
also eliminate some unwholesome practices. Thus all auditors should update and acquire forensic auditing skills to be more effective in the changing situation accountants would found themselves.

2. As crime evolves so should forensic auditors skill in fraud investigation be updated to match with changing world, as well as, technological advancement. The professional bodies should assist in the update activities in that direction.

3. Training and retraining of forensic accountants on court process to avoid loss of good cases to avoidable court technicalities. Reputable legal firms could be used for such training. Also, training on determination of appropriate damages would help in fraud remediation.

\section{References}

Adams, R. A. (2006). Public Sector Accounting and Finance made simple. (Revised edition). Lagos: Corporate Publishers Ventures

Adekoya, A. A., Oyebamiji, T. A. \& Lawal,A. B. (2020). Forensic accounting, tax fraud and tax evasion in Nigeria-review of literature and matter for policy consideration. International Journal of Emerging Trends in Social Sciences 1, 21-28. DOI: 10.20448/2001.91.21.28

Adesina, K., Erin, O., Ajetunmobi, O., Ilogho S. and Asiriuwa , O.(2020). Does forensic audit influence fraud control? Evidence from Nigeria deposit money banks. Banks and Bank System ,15(2),214-229.

Agu, S.I. \& Okoye.E. I . (2019). Application of forensic accounting : A bridge to audit expectation gap in Nigeria deposit money banks in Enugu State. International Journal of Science and Research, 8(3), 46-55.

Aguolu, O. (2018). Fundamentals of auditing ( $4^{\text {th }}$ ed.). Enugu: Meridian Associates

Association of Certified Fraud Examiners (2019). International fraud examiner manual

Bassey, B. E.\& Ahonkhai, O. E. (2017). Effect of forensic accounting and litigation support on fraud detection in Nigeria. Journal of Business and Management, 19 (6), 56-60.

Constitution of the Federal Republic of Nigeria (Promulgation) 1999 No 24 (with amendments)

Crruption Perceptions Index, (2019). https://www.transparency.org/files/content/pages/2019 CPI Report EN.pdf

Ejike, S. I. (2018). The relevance of forensic accounting: Issues in accounting and auditing practice in Nigeria. Journal of Humanities and Social Science, 23(7), 17-24.

Fiergbor, D. D. (2020). Managing projects using forensic accounting in detection and prevention of fraud in Ghana. https://www.researchgate.net/publication/343965757

Gbegi, D. O. \& Adebisi, J. F. (2014). Forensic accounting skills and techniques in fraud investigation in the Nigerian public sector. Mediterranean Journal of Social Sciences, 5(3), 243-253

Hopwood W. S. Leiner, J. J. \& Young, G.R. (2009). Forensic accounting, McGraw-Hill international

Jonathan, G. E. (2015). Jonathan explains 'Stealing is not Corruption'. Form https://www.youtube.com/watch?v=h88U_0AHy7A.

Meigs, W. T, Larsan, E. J. \& Meigs, R. F. (1977). Principles of auditing, 6th edition. Homewood, Illinois. Richard D, Irwin Inc

Merton, H. K. (1957). Social theory and social structure. Glencoe, UK: Free Press

Murphy, D. S. \& Robinson, M. B. (2008). The maximize: Clarifying Merton's theory of anomie and strain. Theoretical Criminology, 12,502-521

NNPC Report https://www.abuja-ng.com/NNPC-FORENSIC-AUDIT-REPORT.html

Okafor, B. E, (2006). Forensic accounting and interview process. Lecture UNIZIK, Awka. Unpublished

Okoye, E. I. (2016). Anatomy of fraud and corruption in Nigeria: A search for the Pandora box and panacea. 32nd inaugural lecture of Nnamdi Azikiwe University, Awka, held on Thursday 18th August at University Auditorium. Onitsha. Noben Press LTD

Okoye, E. I. Adeniyi, S. I \& James, O. N. (2019). Effect of forensic accounting on fraud management on selected firms in Nigeria. International Journal of Economics, Business and Management Research, $3(12), 149-170$

Okoye,E. I. (2008). Foresic audit/accounting vis-avis financial statement fraud. Being paper presented to ANAN, Anambra chapter during the quarterly meeting on 30th June.

Onwubiko, C. O., Nwankwo, A, H. \& Achara, O.L. (2019). Forensic accounting as a tool in managing fraud in organisation: A study of selected firms in Nigeria. Advanced Journal of Management, Accounting and Finance, 4(11), 31-39.

Osisoma, B. C. (2012). Fraud prevention in Nigeria: Applying the forensic accounting tool. Paper presented at a three-day workshop on 'The effective accounting officer in the current financial challenges. Organised by Entrepreneurship Centre, University of PortHarcourt, July 13 
Oyedkun, G.E (2019). Forensic accounting: Curbing fraudulent activities in Mainoma, M.A.\& Oyedekun G.E ed. Forensic accounting research developments, Lagos: Association of Forensic Accounting Researchers (AFAR)

Oyedokun, G.E. (2012).Fundamentals of forensic accounting and fraud examination. Lagos: AARO Publishing Company

Singleton T. W., Singleton A. J., Bologna G. J. \& Lindquist R. J. (2006), Fraud auditing and forensic accounting, (3rd ed), New Jersey: John Wiley \& Sons.

Udeh, S.N.\& Ugwu, J. I. (2018).Fraud in Nigerian banking sector . International Journal of Academic Research in Business and Social Sciences, 8(5), 589-607.

Okoye, E. I., Maimako, S.S., Jugu, Y. G. \& Jat. R. B. (2017). Principles of fraud investigation and forensic accounting .Awka: SCOA Heritage Nigeria LTD.

Vanguard (2020) August 8, https://www.vanguardngr.com/2020/08/fec-approves-appointment-of-8-fieldexperts-for-forensic-auditing-of-nddc/

Webster,s Dictionary,2000. www.werriam.webster,com

World Bank (2020). Nigeria release report on poverty and inquality. https://www.worldbank.org/en/programs/lsms/brief/nigeria-releases-new-report-on-poverty-andinequality-in-country

Zysman, A. (2004). Forensic accounting demystified world investigation network standard practice for investigative and forensic accounting engagement. Canadian Institute of Chartered Accountants 